\title{
WBREW ZWYCZAJOM I TRADYCJI. INTERPRETACJA METAFORY ,NIE JEST DOBRZE ZABIERAĆ CHLEB DZIECI I RZUCAĆ PIESKOM" (MK 7,27B) Z PERSPEKTYWY SYROFENICJANKI
}

Zarówno w językoznawstwie jak i biblistyce badania nad punktem widzenia mają kilkudziesięcioletnią tradycję. ${ }^{1} \mathrm{O}$ ile jednak biblistyka czerpie głównie z teorii G. Genette’a i F.K. Stanzela, ${ }^{2}$ o tyle w badaniach języko i literaturoznawczych nastąpiło rozszerzenie refleksji fokalizacyjnej o aspekty kulturowe i analizy językowo-literackich wykładników zróżnicowań płciowych, etnicznych, ideologicznych, problematykę reprezentacji oraz interpretacji rzeczywistości, kreowania podmiotu mówiącego i budowanie narracyjnej tożsamości. ${ }^{3}$ Prezentowany artykuł ma na celu zwrócenie uwagi na zmianę perspektyw w dialogu Jezusa z Syrofenicjanką - z punktu widzenia opartego na żydowskich tradycjach i doświadczeniach religijnych, reprezentowanego przez Jezusa, na punkt widzenia oparty na hellenistycznych tradycjach kulturowo-obyczajowych i domowym doświadczeniu, reprezentowany przez Syrofenicjankę.

Podstawą analiz będzie tekst z Ewangelii Marka (7,24-30), choć tam, gdzie to konieczne, zwłaszcza by wykazać różnice w przyjętym przez podmiot mówiący punkcie widzenia, pojawią się również odniesienia do relacji Mateuszowej $(15,21-28)$. Obaj hagiografowie w podobny sposób opisują spotkanie Jezusa z kobietą, która nie była

1 Por. S. S z y m i k, Podstawowe aspekty analizy narracyjnej tekstu biblijnego, RBL 49/1996, s. 90-103.

2 J. C z e r s k i, Metodologia Nowego Testamentu, Opole 2012, s. 158-159; R. B a r t n i c k i, K. K ł ó s e k, Metody interpretacji Nowego Testamentu. Wprowadzenie, Kraków 2014, s. 233-236.

3 J. B a r t m i ń s k i, S. N i e br z e gow s k a - B a r t m iń s k a, R. N y c z, Od redakcji, w: c i ż (red.), Punkt widzenia w tekście i dyskursie, Lublin 2004, s. 7. 
Żydówką, ale przyszła prosić o uzdrowienie córki opętanej przez nieczystego ducha. Opisy różnią się w szczegółach, co spowodowane jest inną grupą odbiorców, przyjęciem przez narratora ich perspektywy odbiorczej i ekspozycją innych motywów teologicznych. Doskonale widać to już przy wprowadzeniu głównej - obok Jezusa - boha-

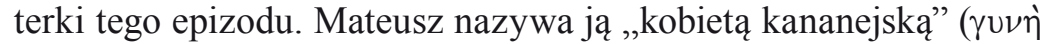
$\left.\mathrm{X} \alpha \nu \alpha \nu \alpha i^{\prime} \alpha\right)$, Marek - „Greczynką, z pochodzenia Syrofenicjanką”

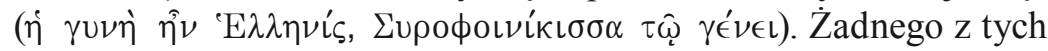
określeń nie należy traktować jako ścisłego wskazania narodowości czy pochodzenia kobiety. Hagiografom chodzi o mocne zaznaczenie faktu, że nie jest ona Żydówką. A ponieważ Ewangelia Mateusza skierowana jest przede wszystkim do judeochrześcijan i częściej niż inne synoptyczne teksty nawiązuje wprost do historii i tradycji Izraela, ewangelista używa określenia „Kanaan” brzmiącego archaicznie już w czasach Jezusa, ale kojarzącego się z dziejami patriarchów i Mojżesza. Marek z kolei kieruje swój przekaz do etnochrześcijan wywodzących się przede wszystkim z Rzymu, dlatego używa określenia związanego z rzymską administracją - „Syrofenicjanka”. Fenicja, o której tu mowa, administracyjnie należała do prowincji Syrii, co dodatkowo podkreśla odniesienie do stolicy prowincji - Tyru. ${ }^{4}$

\section{Obcość}

Określenia geograficzne, czy to historyczne, czy administracyjne, mają na celu podkreślenie faktu, że kobieta, która przychodzi do Jezusa, jest osobą „,z zewnątrz”. Nie pochodzi z Judei ani z Galilei, gdzie swoją misję rozpoczął Jezus. Jest z pochodzenia Syrofenicjanką. Terminu 'E $2 \lambda \eta \nu$ í hagiograf używa, by dookreślić dominantę kulturową i skontrastować grecki styl życia, obyczajowość, tradycję z usankcjonowaną religijnie tradycją i obyczajowością żydowską. Na zderzenie perspektywy żydowskiej z perspektywą pogańską nakłada

4 W odróżnieniu od Fenicji należącej do prowincji Africa Proconsularis ze stolicą w Kartaginie. 
się dodatkowo męski i kobiecy punkt widzenia. Ten pierwszy reprezentowany jest przez Jezusa, ten drugi - przez Syrofenicjankę.

Cały epizod jest pewnego rodzaju sprawdzianem, czy nauka Jezusa i Jego postępowanie są wobec siebie koherentne. Skoro wcześniej Jezus przekonywał, że skostniałej i zewnętrznej tradycji religijnej nie warto pielęgnować i że nic z zewnątrz nie może uczynić człowieka nieczystym, a ,wszystkie pokarmy uznał za czyste” (Mk 7,15.18-19), spotkanie i prośba Syrofenicjanki są okazją, by zaprezentować to w sposób praktyczny. Syrofenicjanka bowiem w świetle żydowskiego prawa jest potrójnie nieczysta: jako kobieta, jako poganka $\mathrm{i}$ jako ta, która miała bezpośredni kontakt $\mathrm{z}$ dzieckiem dręczonym przez złego ducha. Warto zauważyć, że Marek - aby jeszcze mocniej zaakcentować ten rozziew kulturowo-religijny pomiędzy Żydami i poganami - w charakterystyczny sposób różnicuje terminologię na poziomie narracji oraz mowy zależnej. W narracji, gdy przedstawia kobietę, „której córka miała ducha nieczystego”, używa semickiego określenia $\pi \nu \in \hat{u} \mu \alpha \alpha^{\prime} \kappa \alpha^{\prime} \theta \alpha \rho \tau o \nu$ (w. 25). Wprowadzając mowę zależną,

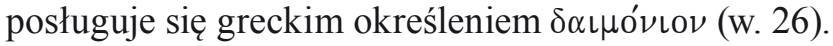

To jednak nie wszystkie opozycje. W zdaniu inicjalnym tego epizodu (w. 24) wspomniane zostało miasto Tyr. ${ }^{5}$ Jest ono nie tylko metonimicznym określeniem narodów pogańskich wrogich Izraelowi, nad którymi w czasach ostatecznych ma się odbyć sąd (por. np. Iz 23, 1-8, J1 3,9; Am 9-10, Za 9,2-4), ale również synonimem dobrobytu, zwłaszcza gdy zestawi się ubogą ludność Galilei i stosunkowo bogatą ludność „terytorium Tyru” ( $\tau \alpha$ ö $\rho \propto \alpha$ Túpov). Te ekonomiczne względy były w czasach powstawania Ewangelii Marka przyczyną napięć między Żydami z Galilei a Fenicjanami z okolic Tyru, o czym wspomina m.in. Józef Flawiusz. ${ }^{6}$ Choć ewangelista Marek nie mówi wprost, że przybyła do Jezusa kobieta była osobą bogatą, to pośrednio czyni aluzje do jej statusu majątkowego. Znana

5 W niektórych kodeksach (a, A, B, K, N, G) pojawia się para Tyr i Sydon, co można uznać za próbę harmonizacji Mk 7,24 i Mt 15,21 oraz Mk 3,8.

${ }^{6}$ G. Te i s s e n, Czasy Jezusa. Tło społeczne pierwotnego chrześcijaństwa, Kraków 2004, s. 71. 
kobiecie sytuacja z dnia codziennego - dokarmianie piesków pod stołem - jest tego doskonałym przykładem. Na trzymanie w domu czworonożnych pupili mogli pozwolić sobie ludzie bogaci. Ponadto córka kobiety, po dokonanym już na odległość egzorcyzmie, odpoczywa na czymś w rodzaju kanapy, sofy ( $\kappa \lambda(\dot{\imath} \nu \eta)$, a nie na prymityw-

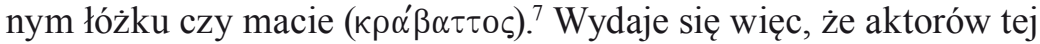
krótkiej, ale wymownej sceny dzieli wszystko: płeć, pochodzenie etniczne, kultura, religia, status majątkowy. Kobieta jest „obca”, „inna”, a mimo to przychodzi do Jezusa, pada Mu do stóp, co jest wyrazem pokory i szacunku, pierwsza rozpoczyna rozmowę z nieznajomym uzdrowicielem i prosi, by potraktował ją jak „swoją” i uzdrowił jej córkę. ${ }^{8}$ Napięcie i dramatyzm rośnie - jak w tej sytuacji zachowa się Jezus? Zgodnie z tym, czego niedawno nauczał, nie powinien zwracać uwagi na nieczystość, obcość, jakąkolwiek niższość kobiety. Zwłaszcza że, przybywając w okolice Tyru, uczynił już krok ku głoszonej inkluzywności i przełamał pewną granicę - zignorował „tradycyjną” wrogość między mieszkańcami Galilei i Tyru. ${ }^{9}$

\section{Rzekoma odmowa}

Jezus, jak się to na pierwszy rzut oka wydaje, potraktował kobietę bardzo ostro, absolutnie niezgodnie z tym, czego nauczał i jak postępował wcześniej. ${ }^{10}$ Relacja Mateusza sprawia wrażenie jeszcze

7 M.A. B e a v i s, Mark, w: M.C. P a r s o n s, Ch. H. T a 1 b e r t (red.), Paideia Commentaries on the New Testament, Grand Rapids 2011, s. 123.

8 Przypomina to nieco epizod z uzdrowieniem sługi (gr. pais dosł. „chłopca”) setnika z Kafarnaum (Mt 8,5-13; Łk 7,1-10). Proszącym jest również bogaty poganin, a uzdrowienie odbywa się na odległość.

9 Przybycie Jezusa w okolice niechętnego Galilejczykom Tyru przypomina z kolei Jego pobyt na terytorium Samarytan, również mocno, choć na innym tle, skonfliktowanych z Żydami (por. J 4, 1-42). Rozmowa z Samarytanką też może kojarzyć się z dialogiem Jezusa z Syrofenicjanką, zwłaszcza że w obu przypadkach zastosowana została „technika nieporozumień”.

10 Chodzi o uzdrawianie pogan wspomniane w Mk 3,8 i 5,1-20. Będzie o tym mowa w dalszej części referatu. 
bardziej brutalnej - Jezus najpierw ignoruje prośby kobiety, a gdy ta, zdesperowana, krzykiem domaga się wysłuchania, uczniowie sugerują swemu mistrzowi radykalne rozwiązanie sprawy: „Odpraw ją!” (Mt 15,23). Wtedy Jezus zauważa, że został posłany tylko (w tekście greckim pojawia się tutaj konstrukcja z podwójnym przeczeniem) do zaginionych owiec z domu Izraela (w. 24). Marek ze względu na swoich odbiorców pomija ten epizod. W jego przekazie Jezus od razu

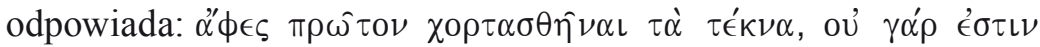

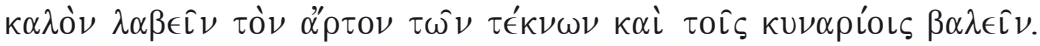
$\mathrm{Na}$ język polski najlepiej przetłumaczyć to zdanie dosłownie jako: „Pozwól, aby najpierw zostały nasycone/nakarmione dzieci; nie jest bowiem dobrze zabierać chleb dzieci ${ }^{11}$ i rzucać pieskom”. Łatwiej jest teraz zauważyć pasywną formę czasownika $\chi 0 \rho \tau \alpha^{\prime} \zeta \omega(\chi 0 \rho \tau \alpha \sigma \theta \eta \hat{\nu \alpha \iota ~-~}$ infinitivus aoristi passivi), co oznacza, że zastosowano tu passivum theologicum. Okazuje się, że już na poziomie składniowym Jezus odnosi swoje słowa do Bożego planu zbawienia. Widać to też na

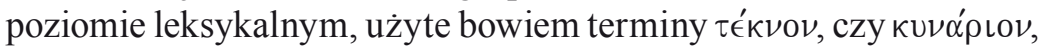
w tym kontekście zaczynają nabierać aluzyjnego znaczenia. Dziećmi, które karmi Bóg, są oczywiście „dzieci Izraela”, czyli Żydzi (por. Wj 4,22; Pwt 14,1;32, 6; Iz 30,1; 63,8; Jr 31, 9; Oz 11,1). Pieskami byliby więc poganie?

Rzeczywiście - w tekstach Starego Testamentu, w czasach międzytestamentowych i nieco później ${ }^{12}$ słowo ,pies” miało charakter pejoratywny, było epitetem stosowanym wobec wrogów, wyrazem pogardy (np. 1Sm 17,43; 2Sm 16,9; Ps 22,17; 59,6n.; Iz 56,10). W wyrażeniach metaforycznych pies był zazwyczaj nośnikiem (domena źródłowa), a wrogowie tematem (domena docelowa) metafory. Zwykle nawiązywano do takich cech jak agresja, głośne ujadanie, niebezpieczeństwo pogryzienia, rozszarpania pazurami, siła, zwłaszcza gdy nośnikiem obrazu była sfora bezdomnych, błąkających się po

11 W wielu polskich przekładach pojawia się tutaj tłumaczenie: „zabierać chleb dzieciom", choć w tekście greckim użyty jest genetivus, a nie dativus.

12 Zob. M. R o s i k, Jezus a judaizm w świetle Ewangelii wedtug św. Marka, Rozprawy i Studia Biblijne 15, Warszawa 2004, s. 561. 
ulicach wielkich psów. Jednak takich cech psa wypowiedź Jezusa nie konotuje. Należałoby zatem rozważyć słowa Nauczyciela z Nazaretu w kontekście tego, co mówił wcześniej, a więc czystości. Psy uważano za zwierzęta nieczyste, przede wszystkim dlatego, że żywiły się padliną (Jr 50,39), albo „wracały do swoich wymiotów” (Prz 26,11). Nic więc dziwnego, że Żydzi z obawy przed nieczystością rytualną, nie trzymali w domach nawet niewielkich psów. Takie małe psy były jednak wiernymi towarzyszami zabaw i ulubieńcami w domach bogatszych Hellenów. Asystowały swoim panom również podczas posiłków, a ponieważ jedzono przy niezbyt wysokich stołach, to psy, które mieściły się pod stołem, musiały być niewielkich rozmiarów. Jezus zatem w swojej sentencji nie odwołuje się do psa jako obrazu agresywnego i groźnego wroga Żydów, ale do psa jako symbolu rytualnej nieczystości. Jednak skoro wcześniej zniósł wszelkie podziały na czyste i nieczyste, to czy przywoływanie teraz zniesionych przepisów i zastosowanie się do nich nie kwestionuje Jego wcześniejszej nauki?

Kluczem do rozwiązania tego problemu jest niewątpliwie użycie

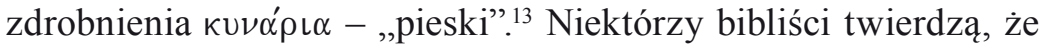
ma to służyć osłabieniu wyrazu pogardy względem Syrofenicjanki, przedstawicielki narodów pogańskich, choć wydaje się to mało przekonujące. Inni uważają deminutiva za specyfikę greki koine w czasach powstawania Ewangelii. ${ }^{14}$ Jeszcze inni akcentują zmianę perspektywy z ogólnej, publicznej, ogarniającej narody, na partykularną, domową, bliską Syrofenicjance i pozostawienie możliwości innej interpretacji niż ta przypisywana Jezusowi. ${ }^{15} \mathrm{Z}$ tymi można się częściowo zgodzić, dodając jeszcze aspekty retoryczne i kompozycyjne.

13 W większości polskich przekładów kynaria tłumaczy się jako „szczenięta”, zapewne ze względu na chęć zachowania pewnej symetrii między „dziećmi” i ,szczeniętami”.

14 M. R o s i k, Jezus a judaizm w świetle Ewangelii wedtug św. Marka, s. 562.

15 Tamże, s. 563. 


\section{Geraza contra Tyr}

Gdyby podstawowym przesłaniem wypowiedzi Jezusa: „Pozwól, aby najpierw zostały nakarmione dzieci; nie jest bowiem dobrze zabierać chleb dzieci i rzucać pieskom" było podkreślanie prymatu Żydów w dostępie do zbawienia, to dziwi postawienie tej kwestii tak stanowczo dopiero teraz. Już w Mk 3,8 wspomina się o tłumach, które słysząc o cudach dokonywanych przez Jezusa, przychodziły do Niego „,z Galilei i Judei, z Jerozolimy, Idumei, z Zajordania oraz z okolic Tyru i Sydonu". Trudno sobie wyobrazić, by Jezus dokonywał selekcji na Żydów i pogan, a następnie uzdrawiał tylko tych pierwszych. Jeszcze bardziej znaczący jest epizod w Mk 5,1-20 - uwolnienie Gerazeńczyka od ducha nieczystego. Wielu biblistów podważa autentyczność tego opisu, powołując się na brak precyzji w określaniu topografii, rozbieżności toponimiczne $\mathrm{w}$ tekstach paralelnych i w rękopisach, nierealność szczegółów (wielotysięczne stada świń ulegające panice i rzucające się z nieistniejącego urwiska w wody jeziora Genezaret). ${ }^{16}$ Część jednak, kierując się erazmiańską zasadą lectio difficilior potior, uznaje tekst za oryginalny. ${ }^{17}$ Można nawet pokusić się o znalezienie paraleli między egzorcyzmem w okolicach Gerazy i egzorcyzmem na odległość - dokonanym w okolicach Tyru. Zarówno Geraza jak i Tyr były miastami mocno zhellenizowanymi; w obu przypadkach Jezus przybywa na terytorium pogan, w obu chodzi o uwolnienie od ducha nieczystego, w obu Jezusowi oddany jest pokłon (Syrofenicjanka robi to jednak bardziej ekspresyjnie - pada do stóp Jezusa;

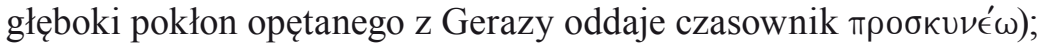
w obu wreszcie pojawia się motyw nieczystych zwierząt.

Przyjęcie tezy, że głównym przesłaniem dialogu z nieżydowską kobietą jest podkreślenie prymatu Żydów w dostępie do zbawienia, jest jeszcze trudniejsze w wersji Mateuszowej. U Mateusza bowiem dialog poprzedzony jest dwoma szczegółowymi opisami uzdrowień,

16 M. Wo j c i e c how s k i, Cuda Jezusa, Częstochowa 2010, s. 89-93.

17 M. R o s i k, Jezus a judaizm w świetle Ewangelii wedtug św. Marka, s. 554 oraz przypisy. 
których beneficjentami są poganie: pierwszy to uzdrowienie sługi setnika z Kafarnaum (Mt 8,5-13) ze schematem bliźniaczo podobnym do spotkania z Kananejką, drugi jest wariantem Markowego uwolnienia od ducha nieczystego w Gerazie (w Mt 8,28-34 cud wydarzył się w kraju Gerazeńczyków i dotyczy dwóch opętanych).

Jeśli zatem głównym przesłaniem sentencji Jezusa nie jest podkreślenie prymatu Żydów, to co stanowi jej zasadniczą treść? Wydaje się, że można tu dostrzec elementy strategii pejrastycznej - z jednej strony Jezus testuje wiarę Syrofenicjanki, z drugiej - jak już wspomniano - spotkanie z Syrofenicjanką jest okazją do „poddania próbie” koherencji nauczania i postępowania Jezusa. ${ }^{18}$ Pejrastyka, doskonale komponująca się z judeo-hellenistycznym klimatem tego fragmentu, zastosowana jest tu zarówno na poziomie dialogu, jak i na poziomie narracji. Odbiorcy Markowej Ewangelii, którzy mają w pamięci poprzedni passus - o czystości i nieczystości, o wierności skostniałej tradycji lub jej łamaniu - doskonale uchwycą ten moment napięcia: Czy Jezus, nauczając wcześniej o konieczności przełamywania tradycji i stereotypów, zastosuje to również w tym przypadku? Przytoczenie sentencji odwołującej się do żydowskiej tradycji i utrwalającej negatywne postrzeganie innych narodów: dzieci Boże to Żydzi, pieski to poganie, początkowo może sprawiać wrażenie niespójności słów i czynów Jezusa: oto ten, który zniósł podział na czyste i nieczyste, teraz chce wrócić do podziału na lepszych - czystych Żydów i gorszych - nieczystych pogan, nie zważając, że jest to również niezgodne $\mathrm{z}$ odwróconą hierarchią królestwa Bożego. Jednak rozwinięcie tej historii, pozwolenie, aby kobieta zaproponowała swoją interpretację, i - co najważniejsze - przyjęcie tej interpretacji jako uprawomocnionej, równoległej niejako z tradycyjną, ${ }^{19}$ sprawia, że Jezus staje się wiarygodny, a jego nauczanie koherentne z czynami.

18 J. C a m e r y - H o g g a t t, Irony in Mark'Gospel, Cambridge 1992, s. 150-151.

19 Otwarcie na nową perspektywę w interpretacji nie neguje implikowanego w sentencji Jezusa prymatu Żydów, sprawia jednak, że nie jest on postrzegany jako dominujący w tym kontekście. 


\section{Próba wiary}

Zanim nastąpi opis konsekwencji przyjęcia przez Jezusa interpretacji zaproponowanej przez Syrofenicjankę, należy kilka słów poświęcić ironii pejrastycznej zastosowanej wobec kobiety. Powtórzmy: oto do Jezusa przychodzi pogańska kobieta i prosi z pokorą i szacunkiem zarazem, aby uzdrowił jej córkę „mającą ducha nieczystego”. Jezus, zamiast docenić wiarę i determinację kobiety, stara się ją zniechęcić, uświadamiając jej, jak Żydzi postrzegają pogan. Wykorzystując fakt, że Syrofenicjanka jest osobą znającą kulturę hellenistyczną i zapewne również założenia retoryki, Jezus rzuca kobiecie wyzwanie, aby przez ciętą ripostę potwierdziła Jego stanowisko. ${ }^{20}$ Tak się w istocie dzieje, jednak Syrofenicjanka nie potwierdza treści sentencji „nie jest dobrze zabierać chleb dzieci i rzucać pieskom”, lecz wcześniejsze pouczenia Jezusa na temat zniesienia pojęcia rytualnej czystości i nieczystości. Będzie o tym jeszcze mowa.

Próbę wiary można jednak odczytać bez odwoływania się do wyrafinowanych technik retorycznych. Jezus bada determinację i zaufanie kobiety. Po tym, jak prośba o uzdrowienie córki została pozornie odrzucona lub przynajmniej jej realizację odsunięto w czasie, aż „zostaną nakarmione dzieci”, można by się spodziewać, że kobieta zrezygnuje i/lub zwróci się do innych uzdrowicieli czy egzorcystów. Wiadomo, że wędrowni i stacjonarni taumaturgowie działali również w środowisku greckim. Najbardziej znanym był współczesny Jezusowi Apollonios z Tyany, przedstawiony później przez Filostratosa w sposób bardzo podobny do ewangelicznych przedstawień Jezusa. Do żydowskich egzorcystów kobieta zwrócić by się nie mogła, pozostawała dla nich, jak wspomniano, potrójnie nieczysta. Fakt, że zwróciła się do Jezusa, kiedy tylko o Nim usłyszała (w. 25), świadczy, że wśród wieści o Jego dokonaniach musiały być informacje o uzdrowieniach nie-Żydów, a być może też o Jego nieortodoksyjnych poglądach na temat czystości i nieczystości i elastycznym podejściu do tradycji (por. Mk 2,18-28; 3,2.4; 7,2-4). W innym przypadku

20 J. C a m e r y-H o g g a t t, Irony in Mark'Gospel, s. 150. 
mało prawdopodobne, aby Syrofenicjanka zdecydowała się zakłócić spokój żydowskiego taumaturga - Jezusa (por. Mk 7,24). Znajomość żydowskich zwyczajów i przepisów puryfikacyjnych nie musiała wynikać z pogłębionej wiedzy religijnej i świadomości teologicznej, jaką się często Syrofenicjance przypisuje. Jako matka, pragnąca za wszelką cenę pomóc dziecku, kobieta najprawdopodobniej szukała środków zaradczych w różnych miejscach (np. w świątyni Asklepiosa) i u różnych ludzi.

W błyskotliwej odpowiedzi Syrofenicjanki na ironię pejrastyczną Jezusa - nota bene kobieta podejmuje grę i stosuje tę samą strategięzauważyć można „rozpaloną przez ripostę Jezusa gorliwość i głębię jej zaufania" - jak twierdził Jan Kalwin. Niezależnie od tego, czy maksymę Jezusa rozumie kobieta jako porządek zbawienia (najpierw Żydzi, potem poganie), czy jako obrazek z życia domowego, przekonuje swojego rozmówcę, że karmienie dzieci i piesków może odbywać się równocześnie. Podobnie jak wcześniej w sentencji Jezusa treści teologiczne ujawniały się już na poziomie składniowym, tak i w odpowiedzi Syrofenicjanki zasadniczego znaczenia nabiera użyta przez nią forma czasownika oraz zdrobnienia: „Panie, i pieski pod

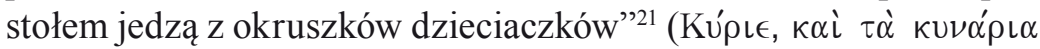

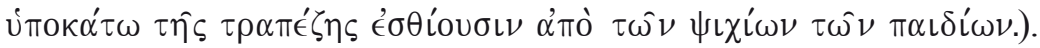

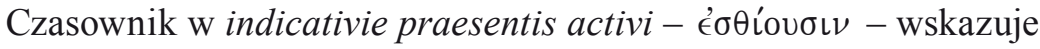
na to, że pieski jedzą w tym samym czasie co dzieci, a nie jak zasugerował Jezus - dzieci muszą zostać nakarmione najpierw. Nikt na tym nie traci, ponieważ dzieciom nie odbiera się chleba, a pieski

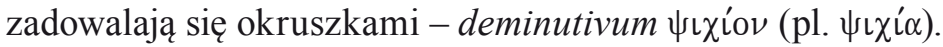

Całą tę odpowiedź Syrofenicjanka odnosi do siebie i swojej aktualnej sytuacji, bez nadawania wypowiedzi głębi teologicznej. Można tutaj obok ironii pejrastycznej dopatrywać się też techniki nieporozumienia często stosowanej w Ewangelii Jana, czyli prowadzenia rozmowy na dwóch różnych poziomach: naturalnym/materialnym

${ }_{21}$ Polskie przekłady nie różnicują zwykle tłumaczenia rzeczownika teknon i zdrobnienia paidion, tutaj chodziło o zaznaczenie użycia dwóch rożnych rzeczowników i formy deminutivum. 
i teologicznym/duchowym. ${ }^{22}$ Jezus teologizuje i uniwersalizuje swoją sentencję, kobieta ją konkretyzuje i kontekstualizuje.

\section{Perspektywa domowa}

W komentarzach często podkreśla się, że Syrofenicjanka okazała się osobą niezwykle inteligentną i błyskotliwą, skoro ostatecznie „wygrywa z Jezusem na argumenty” i otrzymuje najpierw obietnicę uzdrowienia córki: „Idź, demon wyszedł z twojej córki” (Mk 7,29), a następnie wypełnienie tej obietnicy: „Znalazła dzieciaczka, który został położony na sofie, a demon odszedł" (Mk 7,30). ${ }^{23}$ Zakłada się przy tym, że odczytuje ona sentencję Jezusa o pierwszeństwie i uprzywilejowaniu Izraela zgodnie z intencjami nadawcy. Być może wniosek taki można wyciągnąć na podstawie paralelnego tekstu w Ewangelii Mateusza, który rzeczywiście sugeruje, że kobieta kananejska zna zwyczaje i tradycje żydowskie, skoro zwraca się do Jezusa, używając tytułu chrystologicznego osadzonego mocno w tradycji judaistycznej: „,synu Dawida” (Mt 15,22). W relacji Marka nic jednak na to nie wskazuje. Przeciwnie - zarysowana już na początku tego epizodu opozycja: tradycja żydowska, o której wcześniej wypowiadał się Jezus a kultura hellenistyczna, do której przynależy Syrofenicjanka, zdaje się nawet wykluczać poprawne odczytanie sentencji Jezusa na poziomie teologicznym i uniwersalnym. Syrofenicjanka odczytuje ją zatem ze swojej perspektywy - osoby dość majętnej, którą stać na trzymanie w domu piesków, wrażliwej na los zwierząt, ale nie kosztem dzieci. Tę domową perspektywę, punkt widzenia kobiety zaangażowanej w wychowanie dzieci podkreśla familiarność

22 Por. przyp. 6.

23 Zaskakujące, że Mateusz, by odwrócić uwagę od tego zwycięstwa na argumenty, twierdzi, że to wielka wiara kobiety sprawiła, że jej córka została uzdrowiona (Mt 15,28), a Łukasz, choć jego Ewangelia postrzegana jest jako najbardziej przyjazna kobietom, ubogim, wykluczonym, w ogóle pomija ten epizod; zob. M.A. B e a v i s, Mark, s. 124. 


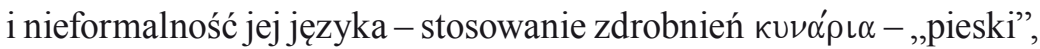
$\psi \iota \chi i ́ \alpha-$, ,okruszki” i $\pi \alpha \iota \delta i ́ \alpha-$,dzieciaczki”.

Jak już wspomniano, kluczowym rzeczownikiem jest tutaj de-

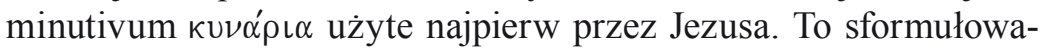
nie podchwytuje Syrofenicjanka i na nim buduje swoją odpowiedź, odnoszącą się do sytuacji znanej jej z codziennego życia, na którą dodatkowo nakłada się kontekst spotkania z Jezusem. Wydaje się zatem, że słowa „nie jest dobrze, aby zabierać chleb dzieci i rzucać pieskom" kobieta traktuje dosłownie i odpowiada również w sposób dosłowny, że karmienie piesków pod stołem okruszkami nie musi oznaczać odbierania chleba dzieciom i może odbywać się jednocześnie z karmieniem dzieci. Tak zapewne wyglądało to w jej domu. A zatem w odpowiedzi kobieta odwołuje się bezpośrednio do własnych dobrych doświadczeń z dziećmi i zwierzętami. Ale na tę dosłowną interpretację zależną od domowych doświadczeń i uwarunkowaną zwyczajami greckimi trzeba jeszcze nałożyć kontekst samego spotkania z Jezusem.

Wiadomo, że Jezus był sławny i rozpoznawalny w Galilei; Marek wielokrotnie wspomina o tłumach, jakie do Niego przychodziły. Niektórzy przychodzący domagali się Jego uwagi, innym wystarczało dotknięcie Jego ubrania, by odzyskać zdrowie (Mk 5,24-29; 6,55-56). To nieustanne nachodzenie przez potrzebujących pomocy musiało być męczące. Z Mk 7,24 wynika, że Jezus udał się na terytorium Tyru nie po to, by głosić tam słowem i czynem dobrą nowinę o królestwie Bożym, ale w poszukiwaniu prywatności i odpoczynku; dlatego gdy „wszedł do pewnego domu nie chciał, aby ktokolwiek o tym wiedział”. Już tutaj można zauważyć otwarcie Jezusa na perspektywę domową, skoro sam szuka domu, w którym mógłby się ukryć i odpocząć od wystąpień publicznych. Choć w tekście dom, do którego Jezus wchodzi, nie został w żaden sposób dookreślony, można się domyślać, że był to dom żydowski, należący do zwolenników Jezusa bądź krewnych Jego uczniów. Do tej pory takie właśnie domy wybierał Jezus, by odpoczywać, ucztować i próbować izolować się od napierających tłumów (por. Mk 1,29.33; 2,1.15; 3,20; 6,10). Charakterystyczne, że 
jeśli właściciel domu nie jest wyraźnie wskazany, rzeczownik oíía, występuje bez rodzajnika, podobnie jak w 7,24. ${ }^{24}$

Okazuje się, że w okolicach Tyru Jezus też nie był postacią anonimową. Jak już wcześniej wspomniano, Jego sława jako skutecznego taumaturga docierała do Fenicji Syryjskiej i ściągała do Galilei mieszkańców tych terenów (Mk 3,8). Być może już wtedy słyszała o nim Syrofenicjanka. Na pewno usłyszała o nim i o jego mocy, kiedy przybył w okolice Tyru, co zbiegło się z chorobą jej córki. Kobieta zdecydowała się prosić Jezusa, by uzdrowił jej dziecko. Zlekceważyła zupełnie Jego pragnienie, by pozostać w ukryciu, mogła się więc spodziewać jakiejś nagany, upomnienia, albo przynajmniej manifestacji niezadowolenia. W tym kontekście słowa „Pozwól, by najpierw nakarmione zostały dzieci, bo nie jest dobrze zabierać chleb dzieci i rzucać pieskom" mogły zostać odczytane właśnie jako forma dezaprobaty dla jej bezceremonialnego zachowania. Frazę „Pozwól, by najpierw zostały nakarmione dzieci” kobieta odczytuje też z punktu widzenia swojego domowego doświadczenia. Jako poganka nie dostrzega zapewne subtelnego passivum theologicum $\mathrm{w}$ formie $\chi 0 \rho \tau \alpha \sigma \theta \hat{\eta} \nu \alpha \mathrm{l}$, ale czasownik $\chi 0 \rho \tau \alpha \zeta \omega$ rozumie nie tylko jako karmienie, ale też sycenie się lub ucztowanie. Skoro tak, w tej

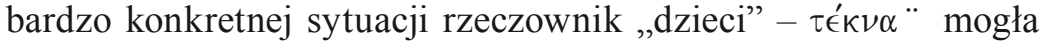
odnieść do zwolenników Jezusa, którzy udzielili Mu gościny. To im należy się pierwszeństwo w ucztowaniu z Jezusem i cieszeniu się Jego obecnością. ${ }^{25}$ Odrywanie Jezusa od uczty i odpoczynku odczytane zostało jako zabieranie chleba, a prośba, by zajął się dziewczynką „mającą ducha nieczystego" - jako „rzucanie chleba pieskom”.

Wartościowane niezbyt pozytywnie określenie „pieski” kobieta odnosi do siebie, ale nie dlatego, że jest poganką, lecz dlatego, że

24 Zob. G. T h e i s s e n, Czasy Jezusa. Tło społeczne pierwotnego chrześcijaństwa, s. 28-29.

${ }^{25} \mathrm{~K}$. Ta gaw a, Miracles et evangile. La pensee personelle de l'evangeliste Marc, Paris 1966, s. 120; cyt. za: W. L. L a n e, The Gospel according to Mark, The New International Commentary on the New Testament, Cambridge 1974, s. 430. 
jej zachowanie przypomina znane jej dobrze zwyczaje piesków. Zwierzęcy ulubieńcy rzeczywiście mogli zakłócać spokojne jedzenie, szczekając pod stołem i domagając się uwagi. Odpowiadając na uwagę Jezusa, jak wspomniano, Syrofenicjanka odwołuje się do swoich pozytywnych doświadczeń z pieskami i przekonuje, że jednoczesne ucztowanie i dokarmianie piesków pod stołem jest możliwe. W kontekście oderwania Jezusa od odpoczynku i posiłku z lokalnymi zwolennikami i/lub uczniami wypowiedź ta nabiera charakteru alegorycznego: Jezus nie musi opuszczać gościnnego domu, by uwolnić dziecko Syrofenicjanki od demona. Kobieta nie domaga się bezpośredniego kontaktu Jezusa z cierpiącą córką, nie chce Go zawłaszczyć (,zabierać chleba”), wystarczy, żeby taumaturg obdarował jej dziecko „okruszkiem” swojej mocy. Wierzyła zapewne, że może On również działać na odległość. Taka alegoryzacja odpowiedzi Syrofenicjanki pozwala wyeksponować jej wiarę. Uzdrowienie dziewczynki jest zatem odpowiedzią na wiarę matki w uzdrawiającą nawet na odległość moc Jezusa. Okazuje się, że Jezus prawidłowo odczytał wypowiedź Syrofenicjanki i to na różnych poziomach: na poziomie retorycznym jako pejrastyczną ironię, na poziomie literalnym jako odwołanie do kobiecego i domowego doświadczenia kobiety i na poziome alegorycznym, który stanowi $\mathrm{w}$ istocie wyznanie wiary tej pogańskiej kobiety. ${ }^{26}$

Odpowiedzią na to wyznanie jest Jezusowy nakaz „Idź”, pojawiający się zwykle tam, gdzie działanie Jezusa spotyka się z głębokim zaufaniem: Mk 2,11; 5,34; 7,29; 10,52. Teraz też wyraźniej widać kontrast między żywą wiarą kobiety, która nie zwraca uwagi na żydowskie obyczaje, tradycje, przepisy rytualne, i brakiem wiary faryzeuszy, którzy skupiają się na zewnętrznym przestrzeganiu nakazów i zakazów i obronie skostniałej tradycji. Syrofenicjanka, jak już wcześniej wspomniano, odchodzi z obietnicą („Idź, demon wyszedł z twojej córki”), która wkrótce zostaje spełniona („demon odszedł" Mk 7,30). Kończąc opis tego cudu, Marek powraca do

${ }^{26}$ Por. M. Ros i k, Jezus a judaizm w świetle Ewangelii wedtug św. Marka, s. 563. 
domowej perspektywy, reprezentowanej przez kobietę. Tym razem nie na poziomie wypowiedzi postaci, lecz na poziomie narracji. Precyzyjne przedstawienie obrazu, jaki zastała wracająca do domu matka, uwzględnia właśnie jej punkt widzenia. W zdaniu „dzieciaczek został położony na sofie" ${ }^{\text {"27 }}$ pojawia się użyte wcześniej przez kobietę deminutivum $\pi \alpha\left\llcorner\delta i^{\prime} \nu^{28}\right.$ które podkreślało emocjonalne zaangażowanie mówiącej, oraz nawiązanie do domowych sprzętów wcześniej był to „stół” $-\tau \rho \alpha \pi \epsilon ́ \zeta \alpha$, teraz jest to „sofa” $-\kappa \lambda i ́ \nu \eta$.

\section{Dynamika tradycji}

Zaproponowana wyżej interpretacja Mk 7,23-30 z punktu widzenia kobiety zajmującej się domem wymaga jeszcze komentarza uwzględniającego szerszy kontekst. Podkreślono już, że w przeciwieństwie do Mk 7,1-15, gdzie Jezus krytykuje integryzm faryzeuszy, brak respektu dla żydowskich przepisów i obyczajów prezentowany przez Syrofenicjankę nie doczekał się nagany. Podyktowany był bowiem żywą wiarą, zaufaniem do Jezusa, pragnieniem nawiązania z Nim relacji. Wiara kobiety, zamanifestowana w jej specyficznym rozumieniu sentencji Jezusa i odpowiedzi na tę sentencję, nie musiała opierać się na tradycyjnym, nawiązującym do judaizmu kojarzeniu

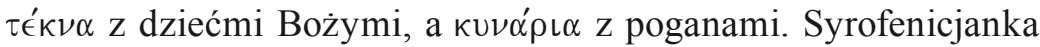
zaproponowała własną interpretację - bardzo osobistą, opartą na domowych doświadczeniach, odwołaniach do hellenistycznej retoryki i obyczajowości. Choć nie pokrywa się ona z pierwotnymi intencjami nadawcy oraz tradycyjnymi implikacjami, Jezus przyjmują ją jako tak samo uprawnioną. W ten sposób rozwiązana zostaje kwestia koherencji słów i czynów Jezusa. Skoro wcześniej krytyce

27 Dziecko zostało położone na sofie zapewne po jakimś gwałtownym, wyczerpującym ataku, w czasie którego demon opuścił dziewczynkę, podobnie jak miało to miejsce w przypadku uzdrowienia chłopca w Mk 9,26.

28 Na temat soteriologicznej interpretacji tego rzeczownika zob. M. R o s i k, Jezus i córka Syrofenicjanki (Mk 7,24-30): wyniesienie do godności dziecka Bożego, STV 40 (2002) z. 2. 
poddana została skostniała tradycja, a podział na czyste i nieczyste zniesiony, to praktycznym potwierdzeniem tego nauczania nie jest tylko uzdrowienie córki Syrofenicjanki. Zresztą cudów, których beneficjentami byli poganie, dokonywał Jezus już wcześniej. Praktycznym potwierdzeniem Jego nauczania o zniesieniu podziałów na czyste i nieczyste i o wyższości dynamicznej tradycji zrodzonej z wiary nad integryzmem jest właśnie akceptacja punktu widzenia kobiety, nawet jego afirmacja, potwierdzenie, że to, co dotąd odrzucano jako nieczyste (pochodzące od pogańskiej kobiety) i obce (nawiązujące do hellenistycznych obyczajów i do sfery prywatnej, domowej, będącej domeną kobiet), należy przyjąć jak czyste i swoje. Syrofenicjanka i jej rozumienie sentencji o dzieciach i pieskach nie dyskredytuje rozumienia tradycyjnego, zakładanego przez Jezusa. Przeciwnie rozszerza dotychczasową alegorię o nowe elementy i odniesienia.

Kalina WOJCIECHOWSKA 